University of South Carolina

Scholar Commons

2014

Contents May Have Shifted: Disentangling the Best Evidence Rule from the Rule Against Hearsay

Colin Miller

University of South Carolina - Columbia, mille933@law.sc.edu

Follow this and additional works at: https://scholarcommons.sc.edu/law_facpub

Part of the Evidence Commons

Recommended Citation

Colin Miller, Contents May Have Shifted: Disentangling the Best Evidence Rule from the Rule Against Hearsay, 71 WASH. \& LEE L. REV. ONLINE 180 (2014)

This Article is brought to you by the Law School at Scholar Commons. It has been accepted for inclusion in Faculty Publications by an authorized administrator of Scholar Commons. For more information, please contact digres@mailbox.sc.edu. 


\title{
Contents May Have Shifted: Disentangling the Best Evidence Rule from the Rule Against Hearsay
}

\author{
Colin Miller*
}

\begin{abstract}
The rule against hearsay covers a statement offered to prove the truth of the matter asserted but does not cover a statement offered for another purpose. Meanwhile, the Best Evidence Rule states that a party seeking to prove the content of a writing, recording, or photograph must produce the original or account for its nonproduction. Does this mean that the Rule is inapplicable when a party seeks to prove something other than the truth of the matter asserted in a writing, recording or photograph? Most courts have answered this question in the affirmative. This essay argues these courts are wrong.
\end{abstract}

Table of Contents

I. Introduction . .187

II. The Rule Against Hearsay and the Truth of the Matter Asserted

III. The Best Evidence Rule and Proving the Content of a Writing, Recording, or Photograph

IV. Conclusion. 


\section{Introduction}

In a divorce action in which a husband and wife vigorously argue over the distribution of marital assets and custody of their children, the wife seeks to testify that she read a torn-up printout of an e-mail sent from her husband to the wife's sister. ${ }^{1}$ In the e-mail, the husband allegedly professes his love for his wife's sister and his plan to divorce his wife and rendezvous with the sister. ${ }^{2}$ The husband's attorney responds that the e-mail contains inadmissible hearsay and that testimony concerning the e-mail would violate the Best Evidence Rule because the wife failed to perform a diligent search for the email. ${ }^{3}$ According to the wife's attorney, the purpose of the wife's testimony is not to prove the truth of the matter asserted in the e-mail: that the husband was actually in love with the sister. ${ }^{4}$ Instead, the wife's testimony would prove the effect of the e-mail on the wife's state of mind and explain why the wife left her husband in Sudan and returned to the United States with the couple's children. ${ }^{5}$

The trial court deems the wife's testimony admissible, and the District of Columbia Court of Appeals later agrees, finding that the explanation given by the wife's attorney killed two birds with one stone: First, the wife's testimony about the e-mail did

* Associate Dean for Faculty Development \& Associate Professor, University of South Carolina School of Law; Blog Editor, EvidenceProf Blog: http://lawprofessors.typepad.com/evidenceprof/.

1. See Abulqasim v. Mahmoud, 49 A.3d 828, 837 (D.C. 2012) (finding no abuse of discretion when a trial court admitted testimony regarding the content of an email that was not itself introduced into evidence).

2. See id. (paraphrasing defendant Mahmoud's testimony regarding the email's contents).

3. See id.

Abulqasim argues that Mahmoud failed to satisfy her burden of proving that she performed a "diligent search for the email," and that her only explanation-that she "ha[d] a whole lot of stuff stolen ... from [her] while [she] was in Sudan ... and [she] believe[d] one of them [wa]s the email"-was insufficient.

4. See id. ("In admitting Mahmoud's testimony concerning the email, the court recognized that testimony about the contents of the writing was hearsay, but ruled that it was not being admitted to prove the truth of a romantic relationship between Abulqasim and his sister-in-law.").

5. See id. at 837-38 ("The court exercised reasonable discretion by admitting the testimony as evidence only to the extent it explained Mahmoud's actions ...."). 
not violate the rule against hearsay because it merely "explained [the wife]'s actions and" was not admitted to prove "the truth of the matter asserted'-the matter asserted being that [the husband] and [the wife's sister] were having a romantic relationship."6 Second, immediately after this statement, the court concludes that, for the same reason, "the best evidence rule did not apply." " In other words, like many courts before it, the Court of Appeals for the District of Columbia conflates the rule against hearsay and the Best Evidence Rule, finding neither rule implicated by the admission of evidence concerning a statement offered to prove something other than the truth of the matter asserted in the statement. ${ }^{8}$ This Essay contends that this conflation reflects a fundamental misunderstanding of the Best Evidence Rule and that courts must disentangle that Rule from the rule against hearsay and find the Best Evidence Rule implicated whenever a party seeks to prove the content of a statement, a concept distinct from the truth of the matter asserted in a statement.

\section{The Rule Against Hearsay and the Truth of the Matter Asserted}

Federal Rule of Evidence 801(c) defines "hearsay" as a statement that:

(1) the declarant does not make while testifying at the current trial or hearing; and

(2) a party offers in evidence to prove the truth of the matter asserted in the statement. ${ }^{9}$

In turn, Federal Rule of Evidence 802 deems hearsay inadmissible in the absence of an exclusion, exception, or federal statute. ${ }^{10}$ Rule 802 deems hearsay evidence presumptively

6. Id.

7. Id.

8. See infra notes $42-43$ and accompanying text (noting that most federal and state courts in similar cases have conflated the rule against hearsay and the Best Evidence Rule).

9. FED. R. EvID. 801(c).

10. FED. R. EvID. 802. 
inadmissible both because such evidence is unreliable and because the jury has an inability to assess that unreliability at trial. As the Supreme Court explained in Williamson v. United States, ${ }^{11}$ Rule 802:

[I] premised on the theory that out-of-court statements are subject to particular hazards. The declarant might be lying; he might have misperceived the events which he relates; he might have faulty memory; his words might be misunderstood or taken out of context by the listener. And the ways in which these dangers are minimized for in-court statements-the oath, the witness'[s] awareness of the gravity of the proceedings, the jury's ability to observe the witness' demeanor, and, most importantly, the right of the opponent to cross-examine-are generally absent for things said out of court. ${ }^{12}$

Essentially, Rule 802 recognizes that the relevance of hearsay evidence depends upon two characteristics that the jury cannot adequately assess: the honesty and accuracy of the declarant when he made the subject statement. ${ }^{13}$ Imagine a case in which Dan is prosecuted for murdering Vince. Ed, an alleged eyewitness, told his friend Fred that he saw Dan shoot Vince, and the prosecution wants to call Fred to testify concerning Ed's statement. Ed's statement is only relevant to prove Dan's guilt if Ed was being both honest and accurate when he made the statement. If Ed was lying in that he actually saw Carl shoot Vince, the statement would not tend to prove that Dan murdered Vince. Similarly, if Ed was inaccurate in that he thought that he saw Dan shoot Vince when it was in fact Carl who shot Vince, his statement would also lack relevance.

If Ed takes the witness stand at trial and testifies that he saw Dan shoot Vince, the jury can assess his credibility after he takes the oath and is subjected to the crucible of cross-

11. 512 U.S. 594 (1994).

12. Id. at 598 .

13. See Christopher B. Mueller \& Laird C. Kirkpatrick, Federal EVIDENCE $§ 8: 3$ (4th ed. 2013) (noting these as two of the primary reasons why hearsay evidence is typically inadmissible); $c f$. State v. Walker, No. 1461, 1977 WL 198855, at *1 (Ohio Ct. App. Apr. 27, 1977) (noting that the "official reports" exception to the rule against hearsay is premised upon the habit of honesty and accuracy of public officials in the performance of their duties). 
examination. ${ }^{14}$ Conversely, if Ed's statement were merely admitted through the testimony of Fred, the jurors would have to rely upon Fred's assessment of Ed's credibility when Ed made the statement rather than being able to draw their own conclusions, which is why Fred's testimony is precluded by the rule against hearsay. ${ }^{15}$

This analysis in turn explains why Rule 801(c)(2) circumscribes the definition of hearsay so that it only covers a statement offered "to prove the truth of the matter asserted in the statement." 16 If a party is not seeking to prove the truth of the matter asserted in a statement, then the jury need not be concerned with the honesty and accuracy of the declarant when he made the subject statement.

Imagine a different case in which Vince has brought a civil battery action against Dan based upon a physical encounter between the two men. Dan claims that he was acting in selfdefense and wants to testify at trial that Ed told him minutes before the encounter, "Vince is coming to see you to collect on that drug debt that you owe him." If Dan is offering this statement to prove that Vince was in fact coming to see him to collect on the drug debt, the statement is classic hearsay as it is a statement offered to prove the truth of the matter asserted. ${ }^{17}$ Indeed, if we assume that Ed's statement must be based upon someone-likely Vince-telling him about Vince's plan to collect on the drug debt, then the statement is hearsay within hearsay. ${ }^{18}$

14. Cf. Crawford v. Washington, 541 U.S. 36, 61 (2004) (finding that the Confrontation Clause of the Sixth Amendment "commands, not that evidence be reliable, but that reliability be assessed in a particular manner: by testing in the crucible of cross-examination").

15. See, e.g., United States v. Campanaro, 63 F. Supp. 811, 814 (E.D. Pa. 1945) ("The vice of such evidence is that the other person upon whose credibility the jury must rely is not present in court and cannot be subjected to crossexamination.").

16. FED. R. EvID. 801(c)(2).

17. See FED. R. EvID. 801 ("Hearsay' means a statement that... the declarant does not make while testifying at the current trial or hearing[,] and ... a party offers in evidence to prove the truth of the matter asserted in the statement.").

18. See FED. R. EvID. 805 ("Hearsay within hearsay is not excluded by the rule against hearsay if each part of the combined statements conforms with an exception to the rule."). 
On the other hand, Dan could legitimately argue that he is offering the statement not to prove the truth of the matter asserted but to prove its effect on the listener, making it not hearsay. ${ }^{19}$ Specifically, Dan could claim that he is offering the statement to prove that, regardless of whether Ed was being honest or accurate when he made the statement, Dan had every reason to believe the statement, placing him in reasonable apprehension of Vince. ${ }^{20}$

In this sense, Dan's testimony would be no different than if Dan were to testify that he heard some other non-hearsay sound such as a dog barking or a doorbell ringing. The barking and the ringing are not hearsay because neither is a statement made by a person, and Dan could not call the dog or the doorbell to the witness stand to have the jury assess their credibility. ${ }^{21}$ Instead, the only question with such testimony would be whether Dan actually heard the dog barking or the doorbell ringing, making the admissibility of his testimony a question of personal knowledge under Federal Rule of Evidence $602^{22}$ and not a hearsay question under Rule $802 .{ }^{23}$ If it is irrelevant to the jury whether Ed was being honest and/or accurate when he made the subject statement, then Ed is the functional equivalent of the dog or the alarm clock, and there is no reason to call him to the witness stand. This is why courts regularly say that a statement

19. See, e.g., United States v. Dupree, 706 F.3d 131, 136 (2d Cir. 2013) (noting that "a statement offered to show its effect on the listener is not hearsay").

20. See, e.g., State v. Silveira, 503 A.2d 599, 609 (Conn. 1986) ("If offered to show his reasonable apprehension of danger it is not offered for a hearsay purpose; its value for this purpose does not depend on the truth of the statement." (quoting MCCORMICK ON EvidENCE $§ 231$, at 734 (Edward W. Cleary ed., 3d ed. 1984)) (internal quotation marks omitted)).

21. See Colin Miller, Hear Spot Bark: Washington Court of Appeals Rejects Argument That Dog Barking Constitutes Hearsay, EvidenceProf Blog, (Nov. 15, 2007), http://lawprofessors.typepad.com/evidenceprof/2007/11/hear-spotbark-.html (last visited Dec. 12, 2014) (discussing "animal hearsay") (on file with the Washington and Lee Law Review).

22. See FED. R. EvID. 602 ("A witness may testify to a matter only if evidence is introduced sufficient to support a finding that the witness has personal knowledge of the matter.").

23. See FED R. EvID. 602 advisory committee's note (noting that a witness may testify to a fact that he or she actually observed). 
is not hearsay if the only question is "whether the statement was made [and] not whether it was true." 24

Another type of statement that is not hearsay because the sole concern is whether the statement was made is a statement of independent legal significance. ${ }^{25}$ One classic example of such a statement is a contract, which "is a verbal act." ${ }^{26}$ Assume that Paul offers Dennis $\$ 500$ if Dennis paints Paul's house, and Dennis accepts Paul's offer. If Paul later sues Dennis for breach of contract, Paul can testify concerning Dennis's acceptance without regard to the rule against hearsay because Paul is not seeking to prove the truth of the matter asserted: that Dennis actually intended to paint the house. When Dan agreed to Paul's offer, he could have had every intention or no intention at all to paint the house, and it would not have mattered: When Dennis stated that he accepted Paul's offer, it created a legally binding contract, regardless of what Dennis might have been thinking to himself. ${ }^{27}$

A final type of statement that is not hearsay because the only concern is whether the statement was made is a statement offered to impeach a witness. Imagine in the prior example that Paul later sought to sell his house and had a realtor, Regina, over to look at his house while his neighbor, Ned, was present. At that time, Regina told Paul and Ned that the paint on his house looked fine and that it should not be a hindrance to Paul in selling his house. Thereafter, when Paul sues Dennis for breach of contract, Paul calls Regina to testify that one of the main reasons that Paul's house had not sold and was still on the market was that the paint on his house looked terrible. If Dennis calls Ned to testify to Regina's earlier statement, he could argue that he is offering the statement for a legitimate non-hearsay

24. Gleason v. Smolinski, No. NNHCV065005107S, 2012 WL 3871999, at *12 (Conn. Super. Ct. Aug. 10, 2012).

25. See, e.g., Kepner-Tregoe, Inc. v. Leadership Software, Inc., 12 F.3d 527, 540 (5th Cir. 1994) ("Signed instruments such as wills, contracts, and promissory notes are writings that have independent legal significance, and are nonhearsay." (quoting ThOMAs A. MAUET, FUNDAMENTALS OF TRIAL TECHNIQUES 180 (2d ed. 1988)) (internal quotation marks omitted)).

26. $I d$.

27. See id. ("Under the objective theory of contracts, the fact that two parties signed a contract is enough to create legal rights, whatever the signatories might have been thinking when they signed it."). 
purpose: to impeach Regina's testimony by revealing to the jury the inconsistency between that testimony and her prior statement. ${ }^{28}$ Such impeachment is permissible under Federal Rule of Evidence 613 and is not hearsay under Rule 801 because it is offered to attack the credibility of the witness and not to prove the truth of the matter asserted in the prior statement: that the paint on the house actually looked fine. ${ }^{29}$

\section{The Best Evidence Rule and Proving the Content of a Writing, Recording, or Photograph}

The Best Evidence Rule is found in Federal Rules of Evidence 1001 to $1008 .{ }^{30}$ Federal Rule of Evidence 1002 sets forth the general Best Evidence Rule: "An original writing, recording, or photograph is required in order to prove its content unless these rules or a federal statute provides otherwise." ${ }^{31}$ Originally propounded in the pre-photocopy days when scriveners and scribes made handwritten copies of documents, the Best Evidence Rule is based upon the "understanding of the central position that the written word occupies in the law and the knowledge that 'a slight variation of words may mean a great difference in rights." 32 Currently, a proponent seeking to prove the content of a writing, recording, or photograph can satisfy the Best Evidence Rule by (1) complying with Rule 1002 by producing the "original"

28. See, e.g., United States v. Pridgen, 518 F.3d 87, 90 n.1 (1st Cir. 2008) (noting that Federal Rule of Evidence 613(b) permits evidence of a prior inconsistent statement to impeach a witness's credibility even when the statements would not have been admissible as substantive evidence).

29. See FED. R. EvID. 613 (providing that extrinsic evidence of a witness's prior inconsistent statement may be admissible "if the witness is given an opportunity to explain or deny the statement and an adverse party is given an opportunity to examine the witness about it").

30. See FED. R. EvID. 1001-1008 (listing rules regarding the admissibility of evidence used to establish the contents of an original writing, recording, or photograph).

31. FED. R. EvID. 1002.

32. Colin Miller, Even Better Than the Real Thing: How Courts Have Been Anything But Liberal in Finding Genuine Questions Raised as to the Authenticity of Originals Under Rule 1003, 68 MD. L. REV. 160, 166 (2008) (quoting MCCORMicK on Evidence $§ 231$, at 704 (Edward W. Cleary ed., 3d ed. 1984)). 
as defined in Rule 1001(d);33 (2) complying with Rule $1003^{34}$ by producing a "duplicate" as defined in Rule 1001(e); ${ }^{35}$ (3) complying with Rule 1004 by proving (a) a valid reason for nonproduction of the original or (b) that the original "is not closely related to a controlling issue," 36 or (4) having the opposing party admit to the content of the original under Rule 1007. ${ }^{37}$

In some cases, a party will seek to prove the content of a writing, recording, or photograph that does not contain a statement, meaning that there is no potential overlap between the rule against hearsay and the Best Evidence Rule. For instance, in State $v$. Churchill, ${ }^{38}$ a police officer viewed security camera footage of a van entering and exiting a parking lot adjacent to a pizza parlor immediately before and after a safe was cracked in the parlor. ${ }^{39}$ Thereafter, the police officer testified at the defendant's safecracking trial that he arrested the defendant in a van that looked similar to the van that he saw in the security footage. ${ }^{40}$ The Churchill court was forced to address the question of whether this testimony violated the Best Evidence Rule because the footage was not produced at trial, and the court's analysis had nothing to do with the rule against hearsay because there was no statement contained in the footage. ${ }^{41}$

In other cases, however, a party will seek to prove the content of a writing, recording, or photograph that does contain a statement, and most federal ${ }^{42}$ and state $^{43}$ courts in such cases

33. See FED. R. Evid. 1001(d) (defining “original”).

34. See FED. R. EvID. 1003 ("A duplicate is admissible to the same extent as the original unless a genuine question is raised about the original's authenticity or the circumstances make it unfair to admit the duplicate.").

35. See FED. R. EvID. 1001(e) (defining "duplicate" as a "counterpart produced by a mechanical, photographic, chemical, electronic, or other equivalent process or technique that accurately reproduces the original").

36. FED. R. EvID. 1004.

37. See FED. R. EvID. 1007 ("The proponent may prove the content ... by the testimony ... of the party against whom the evidence is offered.").

38. No. 01CA14, 2002 WL 598315 (Ohio Ct. App. Apr. 12, 2002).

39. Id. at *2.

40. Id.

41. See id. at *6-7 (rejecting the argument that defense counsel's failure to object to testimony that may have violated the Best Evidence Rule justified a claim for ineffective assistance of counsel).

42. See, e.g., Cal. Dep't of Toxic Substances Control v. Interstate NonFerrous Corp., 298 F. Supp. 2d 930, 989 (E.D. Cal. 2003) (“[Because the witness] 
have conflated the rule against hearsay and the Best Evidence Rule and deemed neither rule applicable if the party is not seeking to prove the truth of the matter asserted in the statement.

Let us return to the hypothetical with a physical altercation ensuing between Dan and Vince soon after Ed tells Dan, "Vince is coming to see you to collect on that drug debt that you owe him." Assume that Ed does not verbally make this statement to Dan but instead sends the statement to Dan in a text message. For the reasons stated above, Dan could testify about this text message without implicating the rule against hearsay because his testimony would be offered to prove that the message placed him in reasonable apprehension of Vince regardless of whether Ed's statement was honest or accurate. Simply put, Dan's testimony would not be proving the truth of the matter asserted in the text message.

Assume, however, that Dan deletes Ed's text message after the physical altercation because it mentions a drug debt, which could lead to Dan being investigated and possibly prosecuted for drug-related crimes. If Dan wants to testify concerning the text message to prove reasonable apprehension, there is no hearsay problem, but is there a Best Evidence problem? As noted, most courts answer this question in the negative by conflating the rule against hearsay and the Best Evidence Rule and concluding that "[t]he best evidence rule is not applicable if the writing is not offered to prove the truth of the matter therein." 44

This juxtaposition is curious because the Best Evidence Rule makes no mention of "the truth of the matter asserted." Instead, Rule 1002 indicates that the Best Evidence Rule is triggered when a party seeks "to prove [the] content" of a writing, recording or photograph." ${ }^{45}$ For the conflation of the rule against hearsay and the Best Evidence Rule to be correct, "content" must be

is not testifying to the contents of the writings or the truth of the matter asserted, hearsay and best evidence objections do not apply.").

43. See, e.g., State v. Eubanks, 609 So. 2d 107, 110 (Fla. Dist. Ct. App. 1992) ("The best evidence rule is not applicable if the writing is not offered to prove the truth of the matter therein.").

44. Id.

45. FED. R. EvID. 1002. 
analogous to "the truth of the matter asserted." Such an analogy, however, does not hold water.

Merriam-Webster states that when the word "content" is used as a noun, it means "something contained" or "the topics or matter treated in a written work" such as a "table of contents." 46 In the above example, then, the content of the text message is Ed's statement about Vince coming to see Dan to collect the drug debt. Put another way, the "content" of a writing is "the matter asserted," not "the truth of the matter asserted." For the text message to have relevance under the Best Evidence Rule, Dan has to prove that the content of Ed's statement was a warning about Vince coming to collect the drug debt because it was this "matter asserted" that allegedly placed Dan in reasonable apprehension of Vince. If Ed had instead texted Dan that Vince was coming over to give Dan a gift or return Dan's lawnmower, Ed's statement would have no relevance because a statement with this content would not have placed Dan in reasonable apprehension of Vince.

For similar reasons, in Abulqasim v. Mahmoud, ${ }^{47}$ discussed in the introduction, the court was wrong to conclude that the wife's testimony about her husband's "love letter" e-mail to the wife's sister fell beyond the scope of the Best Evidence Rule. ${ }^{48}$ The wife claimed that the e-mail was relevant because it explained why she took the couple's children and returned to the United States. ${ }^{49}$ That e-mail, however, was only relevant if the wife proved that the content of the e-mail was a declaration of love. If the husband was e-mailing the wife's sister to set up a surprise birthday party for his wife, it would have no relevance because it would not provide a reasonable explanation for the wife leaving.

To date, seemingly only one court has explicitly recognized this distinction and disentangled the Best Evidence Rule from the rule against hearsay: the Court of Appeals of North Carolina in Kroh v. Kroh. ${ }^{50}$ In Kroh, a husband, Thomas Kroh, brought an

46. Merriam-Webster's Collegiate Dictionary 269 (11th ed. 2006).

47. 49 A.3d 828 (D.C. 2012).

48. See id. at 837 ("The court exercised reasonable discretion by admitting the testimony ... . [T] [Te best evidence rule did not apply.").

49. Id.

50. 567 S.E.2d 760 (N.C. Ct. App. 2002). 
action against his wife, Teresa Kroh, claiming that she had engaged in illegal wiretapping of his in-home conversations and actions. ${ }^{51}$ At trial, the wife sought to testify that she began wiretapping the husband's conversations and activities because she found veterinary reports alleging that the husband had engaged in acts of bestiality with the family dog. ${ }^{52}$

The trial court deemed this proposed testimony inadmissible, and the Court of Appeals of North Carolina later agreed. ${ }^{53}$ The appellate court actually agreed with Teresa Kroh that she could testify concerning the veterinary reports for the non-hearsay purpose of proving the effect of reading the reports on her state of mind and the reason why she began wiretapping her husband. ${ }^{54}$ Nonetheless, the court still deemed Teresa's testimony inadmissible because she failed to produce or account for her nonproduction of the veterinary reports, meaning that she failed to satisfy the Best Evidence Rule. ${ }^{55}$ According to the court, the reports:

[W]ere not relevant to Teresa Kroh's state of mind except to the extent that she read them and interpreted them. As she was offering these reports into evidence to prove their contents (and how she interpreted those contents, regardless of their actual truth or falsity), Teresa Kroh was required to produce the original reports (under Rule 1002) . . .56

This analysis by the court gets to the heart of the issue. If a party is seeking to prove a statement's "effect on the listener," there is no problem under the rule against hearsay because the party can prove this effect without also proving the truth of the matter asserted. But if a party is seeking to prove a statement's "effect on the reader," there is a potential problem under the Best Evidence Rule because, to prove that effect, the party must prove

51. Id. at 761 .

52. Id. at 764 .

53. See id. (concluding that the expert reports were properly excluded because the expert "failed to properly authenticate the proffered reports").

54. See id. at 764-65 (suggesting that the reports could have been admitted into evidence had they been properly admitted under the rules of evidence).

55. See id. at 765 (excluding the report because "Teresa Kroh was required to produce the original reports ... and to properly authenticate them" and she "failed to do so").

56. Id. 
two things: (1) the content of the statement; and (2) how the party interpreted that content. Without first proving the content of the statement, the party's testimony about how she interpreted that content has no relevance.

This is the fundamental distinction between the rule against hearsay and the Best Evidence Rule. A statement offered to prove something other than the truth of the matter asserted is not hearsay because there is no point in calling the declarant to the witness stand as it is irrelevant whether the declarant was being honest or accurate in making the statement. Conversely, in Vince's battery action against Dan, if Dan wants to testify that Ed sent him a text message warning him about Vince coming to collect a drug debt, it makes a great deal of sense for the text message to be admitted as an exhibit to see whether it actually contained such a warning and thus whether it could have placed Dan in reasonable apprehension of Vince. If the Best Evidence Rule did not apply to Dan's testimony concerning the text message, the jury would simply have to take Dan at his word that he indeed received a text message with the claimed content, just as the jury in Abulqasim had to take the wife at her word that she read an e-mail in which her husband professed his love for the wife's sister. ${ }^{57}$

In both of these examples, the question is simply whether the statement, such as a statement with the content claimed by the party, was made, which, as noted above, ${ }^{58}$ is not the concern of the rule against hearsay. Courts conflating the Best Evidence Rule and the rule against hearsay fail to realize that the Best Evidence Rule is concerned with the question of whether a statement was made. Federal Rule of Evidence 1008 details the respective functions of the judge and the jury in resolving Best Evidence issues, and the jury is tasked with deciding "whether... an asserted writing, recording, or photograph ever existed." 59

57. Abulqasim v. Mahmoud, 49 A.3d 828, 837-38 (D.C. 2012) (admitting the email into evidence "to the extent it explained Mahmoud's actions" and not as evidence supporting the truth of the matter asserted).

58. See supra note 24 and accompanying text (distinguishing evidentiary limitations based on personal knowledge, as opposed to the rule against hearsay).

59. FED. R. EvID. 1008. 
The Fourth Circuit's opinion in Klopman v. Zurich American Insurance Co. of Illinois ${ }^{60}$ both illustrates this point and reveals the consequence of following the hearsay/Best Evidence conflation to its logical conclusion. In Klopman, a former tenant sued Andrew Klopman, his former landlord, for personal injuries connected to exposure to lead paint at the property the tenant rented from Klopman. ${ }^{61}$ Klopman thereafter brought a declaratory judgment action against Zurich American Insurance Company of Illinois, seeking a declaration that the insurance company was obligated to defend and indemnify him in the lead paint lawsuit pursuant to his insurance policy. ${ }^{62}$ The insurance company responded that it never issued such an insurance policy to Klopman, while Klopman claimed that the insurance policy was destroyed in a basement flood, meaning that he could testify about the contents of the policy pursuant to Rule 1004 because it was destroyed in the absence of bad faith. ${ }^{63}$ The Fourth Circuit found that Klopman's proposed testimony was governed by the Best Evidence Rule, with the jury tasked under Rule 1008(a) with deciding whether an insurance policy ever issued. ${ }^{64}$

It is no surprise that the Fourth Circuit found that the Best Evidence Rule applied to testimony concerning a contract-the insurance policy. The Best Evidence Rule can be traced all the way back to the pre-Roman inhabitants of England, who placed great importance on ceremony and "viewed written documents affecting property or contractual rights not as mere indicia of those rights, but as the rights themselves." 65 Thus, contracts and documents affecting property rights such as deeds were the original raison d'etre for the Best Evidence Rule. But, as noted, words of contract are not hearsay because they have independent

60. 233 F. App'x 256, 256-58 (4th Cir. 2007).

61. Id. at 257.

62. Id.

63. See id. at $257-59$.

64. See id. at 258-60 ("[T] original ever existed and whether the other evidence accurately reflects the original's content.").

65. Cynthia A. De Silva, California's Best Evidence Rule Repeal: Toward a Greater Appreciation for Secondary Evidence, 30 MCGEORGE L. REV. 646, 648 (1999). 
legal significance. ${ }^{66}$ Klopman was merely attempting to prove that the insurance company agreed to insure his property, which created a legally enforceable contract, not that it actually planned to honor the policy when push came to shove.

Thus, for centuries, courts have applied the Best Evidence Rule to testimony concerning documents-contracts and deedsnot offered to prove the truth of the matter asserted without ever acknowledging their conflation of that Rule with the rule against hearsay in other opinions. If we take this conflation to its logical conclusion, the Best Evidence Rule does not apply to contracts and deeds, a conclusion that would tear the heart-the very heart that gave life to the Rule-out of Rule 1002.

While courts have not extended the Best Evidence Rule to this logical conclusion, which is really more of a logical extreme, they have frequently found that the Rule does not apply to evidence concerning statements offered to impeach witnesses. For instance, in State $v$. Stramiello, ${ }^{67}$ the defendant appealed his conviction for simple escape from a work release camp, claiming, inter alia, that the trial court erred by allowing the prosecution to question guards from the camp concerning a letter that the defendant allegedly used in making his escape. ${ }^{68}$ At trial, the defendant had testified "that he was in an amnesic state during the time he left the [work release] center and thus could not have the requisite intent to commit the crime of simple escape." ${ }^{69}$ In response, the prosecution called guards to testify that the defendant showed them a letter from a trade school stating that the defendant was enrolled in a special class on the night of his escape. ${ }^{70}$

Because it turned out that no class was scheduled on the night of the defendant's escape, the prosecution's theory was that the defendant forged the letter to facilitate his escape. The prosecution therefore argued to the Supreme Court of Louisiana that its failure to produce or account for the letter did not trigger

66. See, e.g., Bd. of Cnty. Comm'rs of Routt Cnty. v. O’Dell, 920 P.2d 48, 51 (Colo. 1996) (noting that letters "are not 'documents' having independent legal significance such as contracts or deeds").

67. 392 So. 2 d 425 (La. 1980)

68. Id. at 428-29.

69. Id. at 429 .

70. Id. 
Best Evidence Rule scrutiny because it was merely using the letter to impeach the defendant and not to prove the truth of the matter asserted in the letter: that the defendant was enrolled in a special class. ${ }^{71}$ The court agreed, concluding that:

The best evidence rule is applicable only when the purpose of offering evidence of the writing is to establish the truth of statements contained therein. When evidence is not offered for the purpose of proving the truth of a writing's contents, but for the purpose of impeaching a witness, the rule is not applicable.... In the instant case, the state was not attempting to prove the truth of the statements contained in the letter, that is, that defendant was enrolled in a special class that met on the evening in question. On the contrary, the state's theory of the case was that defendant made his escape by presenting a letter which contained the falsehood that defendant was enrolled in the special class. The state used the testimony about the letter to impeach defendant's claim that he was in an amnesic state during the time he left the center and thus could not have the requisite intent to commit the crime of simple escape. Hence, the best evidence rule is not applicable here. ${ }^{72}$

This conclusion once again illustrates the folly of conflating the rule against hearsay and the Best Evidence Rule. While the prosecution was not proving the truth of the matter asserted in the letter, surely it was seeking to prove the matter asserted in the letter-in other words, the letter's content. The letter was only relevant to impeach the defendant if its content contradicted the content of the defendant's testimony. In Stramiello, this meant that the letter was only relevant if its content was a fabricated message from the trade school falsely asserting that the defendant was enrolled in a special class. If the letter shown to guards by the defendant stated that he was having memory problems, or, indeed, if the letter was a genuine letter from the trade school that simply had the date of the class wrong, the letter would not be relevant to impeach the defendant because it would be consistent with his trial testimony. Simply put, in order for a party to impeach a witness with a prior inconsistent statement, the party must first prove that the prior statement was indeed inconsistent with the witness's trial testimony, which

71. $I d$.

72. Id. 
requires proof of the content of the prior statement. Therefore, when the prior statement is contained in a writing, recording, or photograph, the proponent of the evidence must satisfy the Best Evidence Rule.

\section{Conclusion}

The rule against hearsay and the Best Evidence Rule cover similar ground, but they do not cover the same ground. The rule against hearsay deems hearsay evidence presumptively inadmissible because of its unreliability, making the rule inapplicable when reliability is not an issue, such as when a party does not seek to prove the truth of the matter asserted in a statement. The Best Evidence Rule deems secondary evidence concerning the content of a writing, recording, or photograph presumptively inadmissible because the original is the best evidence of its own content. This means that the Rule is inapplicable when a party does not seek to prove the content of a writing, recording, or photograph, but an original's content is different from the truth of the matter asserted in the original. Content is the matter asserted in a writing, recording, or photograph, not the truth of that matter asserted. Therefore, courts conflating the rule against hearsay and the Best Evidence Rule have fundamentally misunderstood the Best Evidence Rule and must disentangle that Rule from the rule against hearsay. 